(c) American Dairy Science Association, 2006.

\title{
Prevention of Fatty Liver in Transition Dairy Cows by Subcutaneous Injections of Glucagon ${ }^{1}$
}

\author{
R. A. Nafikov, ${ }^{\star}$ B. N. Ametaj, ${ }^{\star 2}$ G. Bobe, ${ }^{\star}$ K. J. Koehler,† J. W. Young, ${ }^{\star}$ and D. C. Beitz ${ }^{\star 3}$ \\ *Department of Animal Science, and \\ †Department of Statistics, lowa State University, Ames 50011-3150
}

\section{ABSTRACT}

The main objective of this study was to test the extent to which injecting glucagon subcutaneously for $14 \mathrm{~d}$ beginning at $\mathrm{d} 2$ postpartum would prevent fatty liver development in transition dairy cows. Twenty-four multiparous Holstein cows were fed $6 \mathrm{~kg}$ of cracked corn in addition to their standard diet during the last $30 \mathrm{~d}$ of a dry period to induce postpartum development of fatty liver. Glucagon at either 7.5 or $15 \mathrm{mg} / \mathrm{d}$ or saline (control) was injected subcutaneously 3 times daily for $14 \mathrm{~d}$ beginning at d 2 postpartum. Glucagon at $15 \mathrm{mg} /$ $\mathrm{d}$ prevented liver triacylglycerol accumulation in postpartum dairy cows. Glucagon at $7.5 \mathrm{mg} / \mathrm{d}$ showed potential for fatty liver prevention. Glucagon increased concentration of plasma glucose and insulin and decreased plasma nonesterified fatty acid concentrations. No effects of glucagon were detected on plasma $\beta$-hydroxybutyrate concentrations. Glucagon affected neither feed intake nor milk production. Moreover, milk composition was not altered by glucagon. Milk urea $\mathrm{N}$ concentrations decreased, and plasma urea $\mathrm{N}$ concentrations tended to decrease during glucagon administration, indicating that glucagon may improve protein use. Liver glycogen concentrations were not affected by glucagon. No significant differences in body condition scores were detected among treatments throughout the study. These results indicate that subcutaneous glucagon injections can prevent fatty liver in transition dairy cows without causing major production and metabolite disturbances.

Key words: dairy cow, fatty liver, glucagon, prevention

Received March 25, 2005.

Accepted November 3, 2005

${ }^{1}$ The project was supported by the National Research Initiative of the USDA Cooperative State Research, Education and Extension Service, grant number 99-35005-8576. Publication of the Iowa Agriculture and Home Economics Experiment Station, Ames; project number 3801.

${ }^{2}$ Current address: Department of Agricultural, Food, and Nutritional Sciences, Edmonton, AB, Canada, T6G 2P5.

${ }^{3}$ Corresponding author: dcbeitz@iastate.edu

\section{INTRODUCTION}

Dairy cows during the transition period (3 wk before and 3 wk after parturition) are at high risk for different metabolic disorders, including fatty liver (Drackley, 1999). Prevalence of fatty liver in dairy cows can be as high as 50\% (Jorritsma et al., 2000a). Consequences of fatty liver include decreased reproductive success (Jorritsma et al., 2000b) and suppressed immune functions (Wentink et al., 1999). Fatty liver usually does not develop alone and can be associated with other periparturient diseases such as ketosis, retained fetal membranes, endometritis, displaced abomasum, mastitis, and milk fever (Katoh, 2002; Van Winden et al., 2003). Fatty liver commonly is believed to be a prerequisite for development of ketosis (Mills et al., 1986b; Grummer, 1993; Katoh, 2002). Prevention of ketosis and other metabolic disorders is very important, because these disorders cause substantial economical losses to dairy farmers (Fourichon et al., 1999; Bobe et al., 2004).

Transition dairy cows are in negative energy balance, because they cannot meet nutrient requirements for maintenance, fetal growth, and milk production from feed consumption (Herdt, 2000; Jorritsma et al., 2003). At the onset of lactation, the mammary gland has greatly increased demands for glucose, which is used primarily for lactose biosynthesis, and acetate, which is used for milk fat synthesis. To meet nutrient and energy requirements, cows repartition glucose and mobilize fatty acids from adipose tissue, which result in elevated blood concentrations of NEFA (Grummer, 1993; Drackley, 1999; Herdt, 2000). Excess blood NEFA are taken up by the liver and metabolized in different ways. Nonesterified fatty acids can be oxidized completely to carbon dioxide or incompletely to ketone bodies, esterified into triacylglycerol (TAG) for storage in the liver, or secreted into blood as a part of very low density lipoproteins. When rates of NEFA esterification for storage as TAG exceed the rates of NEFA disposal, fatty liver can develop. Exact causes of fatty liver are unknown; however, any factor that causes increased lipid mobilization from adipose tissue might be responsible. Periparturient ketosis is associated with fatty liver and develops because of increased liver lipid infil- 
tration and decreased liver glycogen (Drackley et al., 1992).

Previously, our group demonstrated that continuous 14-d intravenous infusions of glucagon initiated at $d$ 21 postpartum could treat fatty liver and its associated ketosis in early lactating cows (Hippen et al., 1999). In that study, feeding extra corn to dry cows, combined with energy restriction and dietary supplementation with 1,3-butanediol postpartum (Mills et al., 1986a), were used to induce fatty liver and ketosis. Intravenous infusions of glucagon, however, are not practical for on-farm use, and conditions associated with naturally occurring fatty liver and ketosis could be different from those artificially created in the previous study (Hippen et al., 1999). Based on that study, we decided to test whether subcutaneous injections of glucagon could treat or prevent fatty liver in transition dairy cows. Evaluation of potential effects of glucagon treatment has been done (Bobe et al., 2003b), in which subcutaneous injections of glucagon were administered for $14 \mathrm{~d}$ beginning on $\mathrm{d} 8$ postpartum. Time for treatment administration was chosen based on the fact that cows in a previous study (Hippen et al., 1999) had elevated liver TAG concentrations at $\mathrm{d} 7$ postpartum.

The current study was designed to evaluate the effects of subcutaneous glucagon injections on fatty liver prevention in postpartum dairy cows. Time for initiation of treatment was chosen to be $d 2$ postpartum to prevent maximal accumulation of liver TAG. We hypothesized that subcutaneous injections of glucagon might prevent fatty liver. To test this hypothesis, two objectives were addressed: 1) to determine the effects of subcutaneous injections of glucagon administered for $14 \mathrm{~d}$ beginning at $\mathrm{d} 2$ postpartum on fatty liver development in transition dairy cows and 2) to evaluate the effects of glucagon on selected blood metabolites and insulin, feed intake, and milk production.

\section{MATERIALS AND METHODS}

\section{Experimental Design}

Twenty-four multiparous Holstein cows were assigned randomly to receive saline (control; $\mathrm{n}=8$ ), or $7.5(\mathrm{n}=8)$ or $15(\mathrm{n}=8) \mathrm{mg}$ of glucagon per day. One cow assigned to the 7.5-mg dose of glucagon was removed because it developed prepartum fatty liver before the onset of treatment. During the last 4 wk of gestation, all cows were supplemented with $6 \mathrm{~kg}$ of cracked corn in addition to their regular dry cow diet (Bobe et al., 2003b), which was fed according to NRC requirements (2001), to stimulate postpartum development of fatty liver (Hippen et al., 1999). Cows were housed prepartum in a straw-bedded free-stall barn with free access to water and brome hay. After parturition, they were housed in a tie-stall barn and fed ad libitum a lactation diet (Bobe et al., 2003b) that was formulated to meet NRC requirements (2001).

Beginning at $d 2$ postpartum, cows were injected subcutaneously with either saline $(0.15 \mathrm{M} \mathrm{NaCl})$ or glucagon at 7.5 or $15 \mathrm{mg} / \mathrm{d}$ for $14 \mathrm{~d}$. Injections $(60 \mathrm{~mL})$ were given in the region between the fifth and seventh intercostal space 3 times daily at 8-h intervals. Lyophilized glucagon (donated by Eli Lilly and Co., Indianapolis, IN) was dissolved in $0.15 M \mathrm{NaCl}(\mathrm{pH} 10.25)$ at 41.67 or $83.33 \mathrm{mg} / \mathrm{L}$ to create the 7.5 - and $15-\mathrm{mg}$ doses, respectively. Glucagon solutions were prepared every other day, stored at $4^{\circ} \mathrm{C}$, and used within $48 \mathrm{~h}$. To prevent adherence of glucagon, all glassware and utensils were rinsed with $1 \%$ BSA in $0.15 \mathrm{M} \mathrm{NaCl}$ before use. All cows were treated in accordance with guidelines established by the Iowa State University Committee on Animal Care.

\section{Sampling and Analysis}

Liver. Liver samples were obtained by puncture biopsies at the times averaging $d-4,6,9,16,20,27,34$, and 42 postpartum and stored at $-80^{\circ} \mathrm{C}$ for later analyses for concentrations of total lipids, TAG, phospholipids, total cholesterol, and glycogen. Precalving liver biopsies for d -4 postpartum were collected in a period that ranged from $d-7$ to -1 postpartum. Postcalving liver biopsies were collected on the days mentioned earlier with a maximum of 1-d deviation.

Total lipid concentration in liver was determined gravimetrically according to Folch et al. (1957) with the following modifications. Liver tissue with wet weight between 300 and $400 \mathrm{mg}$ was homogenized in $8 \mathrm{~mL}$ of chloroform-methanol $(2: 1 \mathrm{vol} / \mathrm{vol})$ in a $25-\times 150-\mathrm{mm}$ screw-top extraction tube, and sonicated for $30 \mathrm{~s}$ (model 350 Sonifier, Bronson Sonic Power Corp., Danbury, CT). Samples were shaken for $1 \mathrm{~h}$ (model 75 Wrist-Action Shaker, Burrel Scientific, Pittsburgh, PA), and $2 \mathrm{~mL}$ of $0.15 \mathrm{M} \mathrm{NaCl}$ was added. After mixing for 5 to $10 \mathrm{~s}$, the mixture was centrifuged at $500 \times g$ for 20 min (model $\mathrm{K}$ centrifuge, International Equipment Co., Needham Heights, MA), and the methanol-water layer was aspirated. The chloroform-containing fraction was filtered through a Buchner funnel and a 42.5-mm glass microfiber filter (Whatman International Ltd., Maidstone, UK) that had been washed 3 times with 2 , 4 , and $4 \mathrm{~mL}$ of chloroform, respectively. The extract containing the total liver lipids was dried under constant airflow at $50^{\circ} \mathrm{C}$ for $2.5 \mathrm{~h}(\mathrm{SC} / 48 \mathrm{R}$ sampler concentrator, Brinkmann Instruments, Inc., Westbury, NY). Total liver lipid extraction was performed twice by using the same set of liver samples. One of the extracts was used for analysis of liver phospholipids and total cholesterol, 
and the other was used for determination of total lipids and TAG.

For determination of phospholipids and total cholesterol, dried liver lipid extracts were reconstituted in 5 $\mathrm{mL}$ of $1 \%$ Triton X-405 (Amresco Inc., Solon, OH) in $0.15 \mathrm{M} \mathrm{NaCl}$ at $37^{\circ} \mathrm{C}$, and liver phospholipids (Phospholipids B kit number 991-38492, Wako, Richmond, VA; Takayama et al., 1977) and total cholesterol (Cholesterol kit number C7510, Pointe Scientific, Lincoln Park, MI; Allain et al., 1974) concentrations were determined on a microplate spectrophotometer (Spectra Max Plus, Sunnyvale, CA). For determination of liver TAG, dried lipids were reconstituted with chloroform, and a small aliquot of that solution was used for analysis. After evaporating chloroform, lipids were subjected to alkaline hydrolysis in a solution containing $20 \%$ of $2 \mathrm{~N} \mathrm{KOH}$ and $80 \%$ of $96 \%$ ethanol for $1 \mathrm{~h}$ at $80^{\circ} \mathrm{C}$. The solution mixture then was neutralized with $12.1 \mathrm{~N} \mathrm{HCl}$, and glycerol concentration was determined enzymatically (TAG kit number T7532, Pointe Scientific; Fossati and Prencipe, 1982), and expressed as TAG concentration. Liver glycogen determination was done as described by Bobe et al. (2003b).

Plasma. Blood samples were collected from the coccygeal vein on $\mathrm{d} 1$ to $17,20,27,34$, and 41 postpartum during the morning. During the treatment period, blood samples were collected $1 \mathrm{~h}$ after the morning injection of glucagon or saline. Vacutainer tubes $(10-\mathrm{mL}$, Becton Dickinson and Co., Rutherford, NJ) containing $\mathrm{Na}_{3}-$ EDTA were used for blood sampling. After centrifugation, blood plasma samples were stored at $-20^{\circ} \mathrm{C}$ until further analysis for concentrations of glucose (Glucose kit number 315, Sigma Chemical Co., St. Louis, MO; Trinder, 1969), NEFA (NEFA-C kit number 994-75409; Wako), BHBA (Pointe Scientific; Hansen and Freier, 1978), and plasma urea N (BUN kit number B 7552, Pointe Scientific; Talke and Schubert, 1965).

Plasma NEFA assay was based on the reaction catalyzed by acyl-CoA synthetase, which converts NEFA to their corresponding acyl-CoA. Then, acyl-CoA was oxidized by acyl-CoA oxidase to produce hydrogen peroxide, which can be quantified after conversion to a color product by peroxidase. Ascorbate oxidase was added to the reaction mixture to prevent interference of the assay with ascorbic acid, which can react with hydrogen peroxide.

Plasma insulin concentration was determined by radioimmunoassay using antisera for bovine insulin (bovine insulin antisera, catalog number 1010, Linco Research, Inc., St. Charles, MO). Other reagents for radioimmunoassay were from the rat insulin kit (rat insulin radioimmunoassay kit number $\mathrm{RI}-13 \mathrm{~K}$, Linco Research, Inc.). Bovine insulin (bovine insulin catalog number I 0516; Sigma Chemical Co.) standards were prepared in the prescribed assay buffer.

Other Measurements. Feed intake (as-fed basis) was measured twice daily for postpartum d 1 through 17. Cows were milked at 0630 and $1830 \mathrm{~h}$ and production was recorded daily for $d 1$ through 41 postpartum. Milk samples were collected from 2 successive milkings at d 2,6,9,16,20,27,34, and 41 postpartum, and analyzed for fat, protein, lactose, and urea $\mathrm{N}$ by midinfrared spectrophotometry (Milk-O-Scan 203, Foss Food Technology, Eden Prairie, MN). Body condition scores were evaluated by 3 individuals at postpartum $d-22$, $-9,5,19$, and 32 . Cows were tested twice daily for urinary acetoacetate from postpartum d 0 to 41 (i.e., acetone plus acetoacetate, Ketostix, Miles Inc. Diagnostics Division, Elkhart, IN). The Ketostix urine strip was directly wetted from the urine stream, and the result of the test was read after $60 \mathrm{~s}$, and recorded using a color scale with the range of acetoacetate concentration from 0 to $15,700 \mu M(160 \mathrm{mg} / \mathrm{dL})$.

\section{Statistical Analyses}

Data were analyzed as repeated measures on individual cows by using the MIXED procedure of SAS (SAS Inst. Inc., Cary, NC). Daily dose effects of 7.5 and 15 $\mathrm{mg}$ of glucagon administration on response variables were evaluated by comparing each dose-group response with the control. Separate comparisons were made for data obtained during the treatment period and during the posttreatment period.

A similar analysis was performed for each response variable. The fixed effects were treatment (saline, 7.5, and 15-mg daily dose of glucagon), time, and treatment $x$ time interaction. Measurements from different cows were assumed independent, but the Toeplitz covariance structure was used to model correlations among repeated measurements obtained from each cow. The Toeplitz covariance structure was selected based on the Schwarz's Bayesian information criterion (smaller is better) and the design of the study. The Toeplitz covariance structure assumes homogeneous variances across time points, equal correlations for any pair of measurements equally distant in time, but different correlations for pairs of observations with different separation in time. The logarithmic transformation of some responses was used to approximate more closely normality requirements for performing $t$-test and $F$-test. Overall effects of different doses were evaluated by using $t$-tests to compare changes in response variables across time from each of the 2 glucagon doses with corresponding changes in response variables from the control. Effects of time and time $\times$ treatment interactions were assessed by $F$-tests. The Kenward-Roger option was used to ob- 
tain degrees of freedom for these tests. Significance was declared at $P<0.05$. Means and SEM shown in the figures were calculated from the original, nontransformed data.

\section{RESULTS}

\section{Liver Lipid Composition and Glycogen}

A postpartum increase in liver TAG concentrations was prevented by glucagon administration at $15 \mathrm{mg} / \mathrm{d}$ $(P \leq 0.028$; Figure 1A). Liver TAG concentrations in cows given $7.5 \mathrm{mg}$ of glucagon per d, however, were not suppressed as effectively $(P \leq 0.20)$. Glucagon administration tended to prevent total lipid accumulation by liver of lactating dairy cows (Figure 1B), although the effects of 7.5 and $15 \mathrm{mg}$ of glucagon were not significant $(P \leq 0.096$ and $P \leq 0.057$, respectively). Concentrations of liver phospholipids and total cholesterol (Figure 1C and $1 \mathrm{D}$, respectively) in the glucagon-treated cows were not different from concentrations in the control (liver phospholipids: $P \leq 0.12$ and $P \leq 0.31$ for 7.5 and $15 \mathrm{mg}$ of glucagon per day, respectively; liver total cholesterol: $P \leq 0.41$ and $P \leq 0.32$ for 7.5 and $15 \mathrm{mg} / \mathrm{d}$ of glucagon, respectively). Nevertheless, concentrations of liver phospholipids and total cholesterol tended to be greater in the control than after glucagon administration. Time effects were detected for concentrations of liver TAG, phospholipids, and total cholesterol $(P<0.03, P<0.04$, and $P<0.03$, respectively) for the posttreatment period (d 17 through 41).

Liver glycogen concentrations declined after parturition through d 6 postpartum in all treatments (Figure 2 ). Then, they started to increase at different rates in each treatment, reaching prepartum values around $d$ 34 postpartum. No effects of glucagon administration were detected for liver glycogen concentrations during the treatment period $(P \leq 0.11$ and $P \leq 0.36$ for 7.5 and $15 \mathrm{mg} / \mathrm{d}$ of glucagon treatment groups, respectively). However, glucagon administration at the $15-\mathrm{mg}$ dose increased $(P \leq 0.045)$ in liver glycogen concentrations during the posttreatment period. Liver glycogen concentrations also tended $(P \leq 0.094)$ to be greater for the $7.5-\mathrm{mg}$ dose of glucagon during the posttreatment period than in the control. Time effects were detected on liver glycogen concentrations during the treatment period $(P<0.001)$, and a time $\times$ treatment interaction was detected for the posttreatment period $(P<0.003)$.

\section{Plasma Metabolites}

Plasma glucose concentrations increased during the treatment period in cows given the 7.5- and 15-mg doses of glucagon $(P<0.001$ and $P<0.001$, respectively; Figure $3 \mathrm{~A})$. No significant differences in plasma glucose concentrations were detected after the end of the treatment period. Plasma NEFA concentrations averaged more than $500 \mu M$ in cows from all treatments at about d 2 postpartum (Figure $3 \mathrm{~B}$ ). After glucagon administration, plasma NEFA concentrations declined rapidly compared with those in the control. As a result, plasma NEFA concentrations were less in the glucagon-treated cows $(P \leq 0.046$ and $P \leq 0.007$ for 7.5 - and $15-\mathrm{mg}$ doses of glucagon, respectively) during the treatment period. Time effects were detected for plasma NEFA concentrations during treatment $(P<0.009)$ and posttreatment $(P<0.002)$ periods.

Differences in plasma BHBA concentrations between the control and each dose of glucagon did not differ during the treatment period $(P \leq 0.35$ and $P \leq 0.77$ for the 7.5- and 15-mg doses of glucagon, respectively; Figure 3C). Plasma urea N concentrations for 7.5- $(P \leq$ $0.24)$ and $15-\mathrm{mg}(P \leq 0.17)$ doses of glucagon were not different from the control (Figure 3D). There was a trend, however, for plasma urea $\mathrm{N}$ concentrations to be less in the glucagon-treated groups during the treatment period. Time effects were detected on plasma urea $\mathrm{N}$ concentrations during treatment $(P<0.001)$ and posttreatment $(P \leq 0.034)$ periods.

Plasma insulin concentrations increased steadily after the initiation of glucagon administration (Figure 4). Cows treated with glucagon had greater plasma insulin concentrations than those of the control $(P \leq 0.012$ and $P<0.002$ for $7.5-$ and $15-\mathrm{mg}$ doses of glucagon, respectively) during the treatment period. No differences were detected in plasma insulin concentrations between cows treated with glucagons and the control during the posttreatment period.

\section{Milk Production and Composition}

Glucagon administration did not affect milk production during the treatment $(P \leq 0.78$ and $P \leq 0.51$ for 7.5 and $15 \mathrm{mg} / \mathrm{d}$ of glucagon, respectively) and posttreatment $(P \leq 0.46$ and $P \leq 0.50$ for 7.5 and $15 \mathrm{mg} / \mathrm{d}$ of glucagon, respectively) periods (Figure 5). Time effects on milk production were detected during the treatment $(P<0.001)$ and posttreatment $(P<0.05)$ periods.

Milk lactose concentrations tended to be slightly greater in response to the 7.5-mg dose of glucagon during the treatment $(P \leq 0.19)$ and posttreatment $(P \leq$ 0.11 ) periods compared with the control (Figure $6 \mathrm{~A}$ ). Glucagon administration at the 15 -mg dose had no effect on milk lactose concentrations $(P \leq 0.96$ and $P$ $\leq 0.71$ for the treatment and posttreatment periods, respectively). Time effects on milk lactose concentrations were detected $(P<0.001)$ during the treatment period. Milk fat concentrations were not affected by glucagon during the treatment $(P \leq 0.71$ and $P \leq 0.66$ 

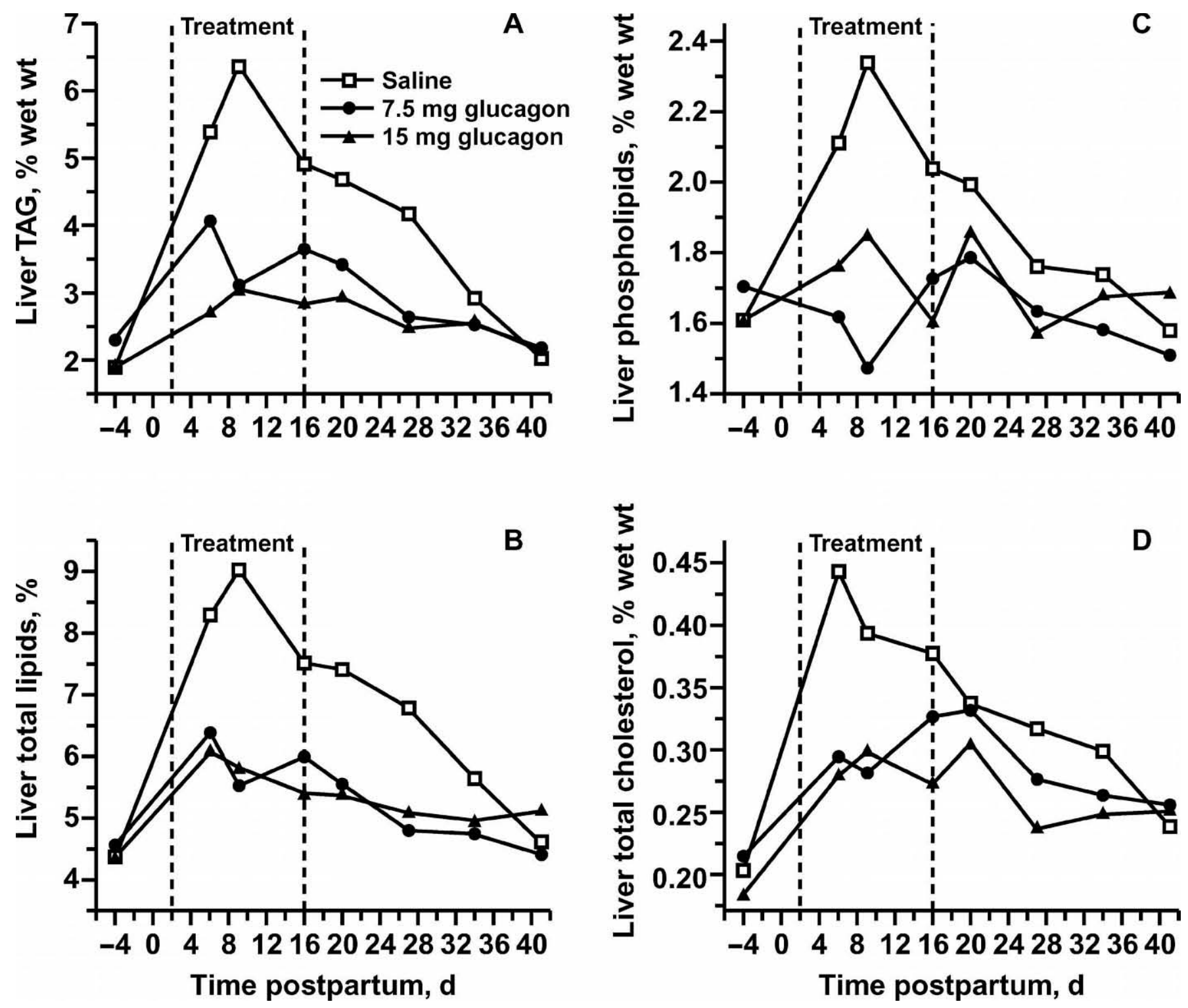

Figure 1. Liver lipid composition of cows treated with saline, $7.5 \mathrm{mg}$, and $15 \mathrm{mg}$ of glucagon per day. A) Liver triacylglycerol. Glucagon effects during the treatment period were not significant for $7.5-\mathrm{mg}$ dose, but differed $(P<0.05)$ for 15 -mg dose. During the posttreatment period, effects were not significant for 7.5 - and $15-\mathrm{mg}$ doses. Time effects for the treatment period were not different; time effects for the posttreatment period differed $(P<0.05)$. Treatment $\times$ time interactions were not detected for the treatment and posttreatment periods $(\mathrm{SEM}=0.38$ to 0.84 ). B) Liver total lipids. Glucagon effects during treatment did not differ for 7.5- and 15-mg doses. During the posttreatment period, effects were not different for 7.5- and 15-mg doses. Time effects for treatment and posttreatment periods were not significant. Treatment $\times$ time interactions for the treatment and posttreatment periods were not significant $(\mathrm{SEM}=0.36$ to 0.78$)$. C) Liver phospholipids. Glucagon effects during treatment did not differ for 7.5- and 15-mg doses. During the posttreatment period, effects were not significant for 7.5- and 15-mg doses. Time effects during the treatment period were not significant. Time effects for the posttreatment period differed ( $P$ $<0.05)$. Treatment $\times$ time interactions were not detected for the treatment and posttreatment periods $(\mathrm{SEM}=0.14$ to 0.22$)$. D) Liver total cholesterol. Glucagon effects during the treatment period were not significant for 7.5- and 15-mg doses. During the posttreatment period, effects were not different for 7.5- and 15-mg doses. Time effects for the treatment period were not significant. Time effects for the posttreatment period differed $(P<0.05)$. Treatment $\times$ time interactions were not detected for the treatment and posttreatment periods $($ SEM $=0.02$ to 0.05$)$.

for 7.5- and 15-mg doses of glucagon, respectively) and posttreatment $(P \leq 0.63$ and $P \leq 0.83$ for 7.5 - and 15 $\mathrm{mg}$ doses of glucagon, respectively) periods (Figure $6 \mathrm{~B}$ ). Time effects on milk fat concentrations were detected $(P<0.004)$ during the treatment period.
Milk protein concentrations declined at the beginning of lactation until they reached baseline concentrations at the end of the treatment period in the range between 2.50 and $2.75 \%$ (Figure 6C). A trend was detected for milk protein to be less in the glucagon-treated groups 


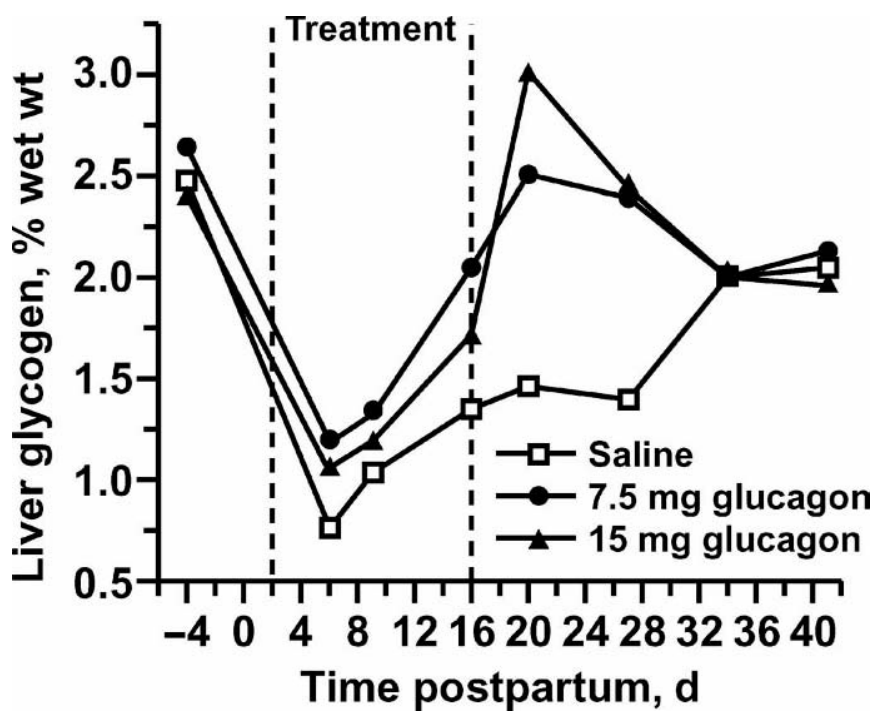

Figure 2. Liver glycogen concentration of cows treated with saline, $7.5 \mathrm{mg}$, and $15 \mathrm{mg}$ of glucagon per day. Glucagon effects during the treatment period did not differ for 7.5- and 15-mg doses. During the posttreatment period, effects of the $7.5-\mathrm{mg}$ dose did not differ from control, but differed $(P<0.05)$ for the 15 -mg dose. Time effects during the treatment period differed $(P<0.001)$. Time effects during the posttreatment period were not significant. A treatment $\times$ time interaction was not detected during the treatment period. A treatment $\times$ time interaction was detected $(P<0.01)$ during the posttreatment period $(\mathrm{SEM}=0.17$ to 0.20$)$.

( $P \leq 0.13$ and $P \leq 0.20$ for $7.5-$ and $15-\mathrm{mg}$ doses of glucagon, respectively) compared with the control during the treatment period, but the magnitude of the difference was small. No differences in milk protein concentrations were detected between glucagon-treated groups and the control during the posttreatment period ( $P \leq 0.64$ and $P \leq 0.83$ for 7.5 and $15 \mathrm{mg} / \mathrm{d}$ of glucagon, respectively). Time effects on milk protein concentrations were detected during the treatment $(P<0.001)$ and posttreatment $(P<0.03)$ periods. Milk urea $\mathrm{N}$ concentrations were greater in the control than in the glucagon-treated groups $(P<0.021$ and $P<0.002$ for 7.5 and $15-\mathrm{mg}$ doses of glucagon) during the treatment period (Figure 6D). No differences in milk urea $\mathrm{N}$ concentrations were detected between the glucagon-treated groups and the control during the posttreatment period.

\section{Feed Intake, BCS, and Urinary Acetoacetate}

Feed intake was not affected by glucagon administration during the treatment period $(P \leq 0.99$ and $P \leq$ 0.95 for 7.5 - and $15-\mathrm{mg}$ doses of glucagon, respectively; Figure 7). Cows given the $7.5 \mathrm{mg}$ dose of glucagon, however, tended to have greater feed intake around d 9 postpartum. No differences in BCS were detected among treatments (Figure 8). Precalving BCS was not as high as in an earlier study (Hippen et al., 1999), which may have decreased the severity of fatty liver development in the present study. Concentrations of acetoacetate in urine were not affected by glucagon administration (data not shown).

\section{DISCUSSION}

The present study showed the ability of glucagon administered subcutaneously to prevent fatty liver development in postpartum dairy cows. Earlier work (Hippen et al., 1999) showed alleviation of fatty liver by intravenous infusions of glucagons. A follow-up study (Bobe et al., 2003b) demonstrated potential use of subcutaneous glucagon injections to decrease the degree of fatty liver in older (3.5 yr and older) early lactation cows. Our current work differs from the earlier studies on fatty liver treatment by glucagon in that we began subcutaneous glucagon injections on $\mathrm{d} 2$ postpartum before the onset of fatty liver had occurred. It should be emphasized that cows in our study developed mild fatty liver with liver TAG concentrations not exceeding $10 \%$ on a wet-weight basis compared with other studies, in which cows with fatty liver had liver TAG concentrations above 10\% (Van Den Top et al., 1995; Hippen et al., 1999). Nevertheless, postpartum liver TAG concentrations observed in our cows are representative of the current situation in dairy industry, in which the majority of postpartum cows with fatty liver have liver TAG concentrations not exceeding a 10\% threshold (Jorritsma et al., 2000a).

Peak of liver lipid accumulation (Figure 1) occurred around d 9 postpartum, which agrees with other results (Greenfield et al., 2000). In other studies, however, peak of lipid accumulation occurred later, but within the first 2 wk of lactation (Van Den Top et al., 1996; Zerbe et al., 2000). Liver phospholipid (Figure 1C) and total cholesterol (Figure 1D) concentrations were similar to those observed in other studies (Van Den Top et al., 1996; Bobe et al., 2003a). The trend for liver phospholipid and total cholesterol concentrations to be greater in controls than in cows treated with glucagon suggests that TAG accumulation in liver is associated with additional membranes surrounding the TAG droplets, composed of phospholipids and cholesterol. Liver phospholipid concentrations were based on the measurements of phosphatidylcholine, which is usually the major phospholipid in animal tissues (Jenkins and Kramer, 1990).

Differences in liver total lipids between the glucagontreated groups and the control (Figure 1B) and the difference in liver TAG between the 7.5-mg dose of glucagon and the control (Figure 1A) were probably not different because of inadequate numbers of cows and the 

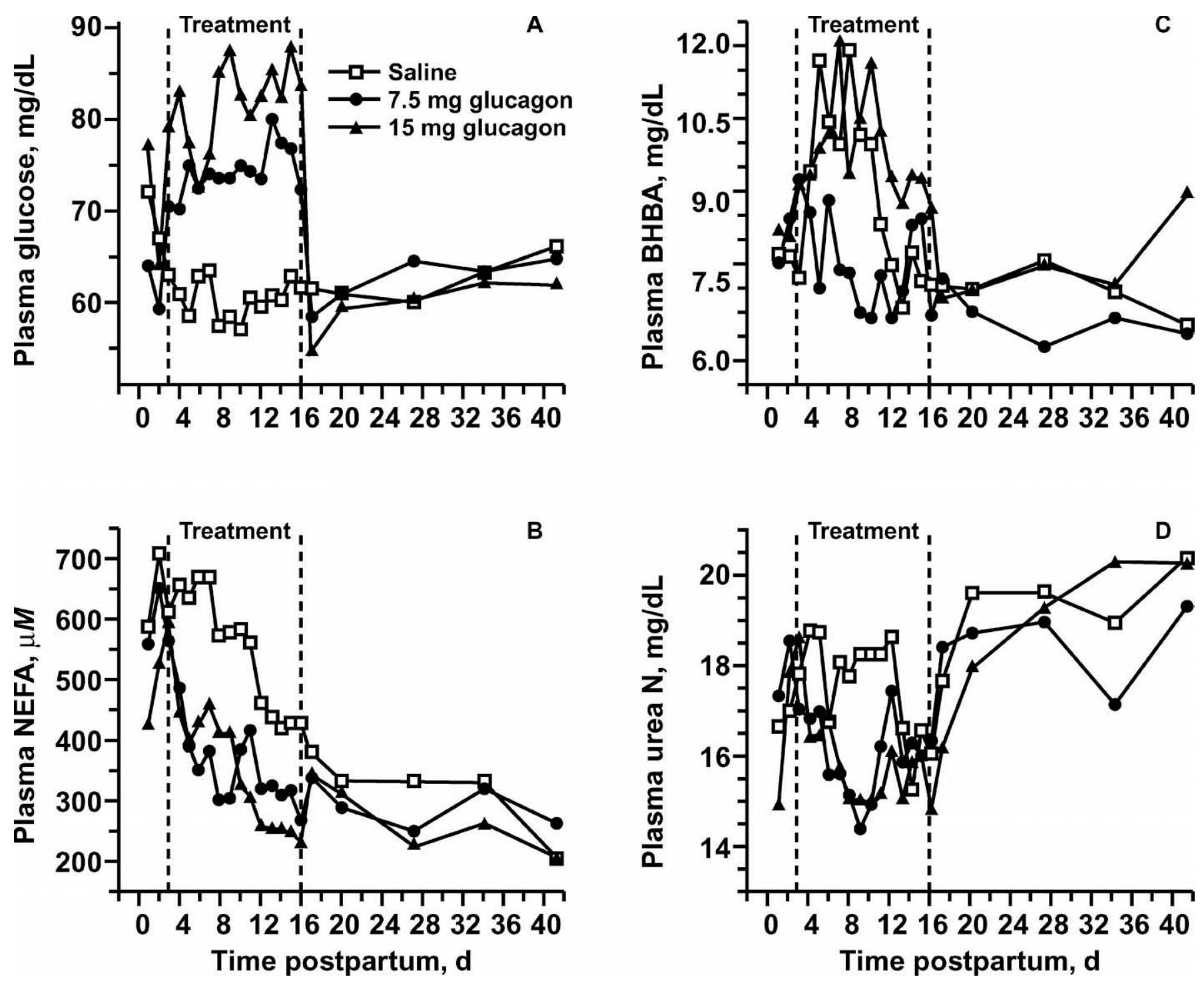

Figure 3. Plasma metabolite concentrations of cows treated with saline, $7.5 \mathrm{mg}$, and $15 \mathrm{mg}$ of glucagon per day. A) Plasma glucose. Glucagon effects during the treatment period differed between the 7.5- and 15-mg doses $(P<0.001$ and $P<0.001$, respectively) and the control. During the posttreatment period, effects were not significant for the 7.5- and 15-mg doses. Time effects during treatment and posttreatment periods were not significant. Treatment $\times$ time interactions were not detected during treatment and posttreatment periods $(\mathrm{SEM}=1.31$ to 1.74$)$. B) Plasma NEFA. Glucagon effects during the treatment period differed between the 7.5- and 15-mg doses $(P \leq 0.046$ and 0.007 , respectively) and the control. During the posttreatment period, effects were not significant for 7.5- and 15-mg doses. Time effects during treatment and posttreatment periods were detected $(P<0.01$ and $P<0.01$, respectively). Treatment $\times$ time interactions were not detected during treatment and posttreatment periods (SEM $=26.5$ to 64.8). C) Plasma BHBA. Glucagon effects during the treatment period were not significant for 7.5- and 15-mg daily dose groups. During the posttreatment period, effects were not significant for 7.5- and 15-mg doses. Time effects for the treatment and posttreatment periods were not significant. Treatment $\times$ time interactions were not detected during treatment and posttreatment periods (SEM $=0.49$ to 1.37 ). D) Plasma urea N. Glucagon effects during the treatment period were not significant for 7.5- and 15-mg doses. During the posttreatment period, effects were not significant for 7.5- and 15-mg doses. Time effects during treatment and posttreatment periods were detected $(P<0.001$ and $P<0.05$, respectively). Treatment $\times$ time interaction was detected $(P<0.05)$ during the treatment period. A treatment $\times$ time interaction during the posttreatment period was not detected $(\mathrm{SEM}=0.76$ to 0.89$)$.

large variability in liver lipids among cows within treatment groups. The percentages of liver TAG, phospholipids, and total cholesterol nearly added up to the percentages of liver total lipids determined gravimetrically, suggesting strongly that analysis of liver lipid composition included all major lipids.
Liver glycogen concentrations (Figure 2) were not affected by glucagon administration as previously shown (Bobe et al., 2003b). This observation indicates that plasma glucose concentrations (Figure 3A) did not increase at the expense of glycogen degradation in glucagon-treated cows. Moreover, glucagon did not inhibit 


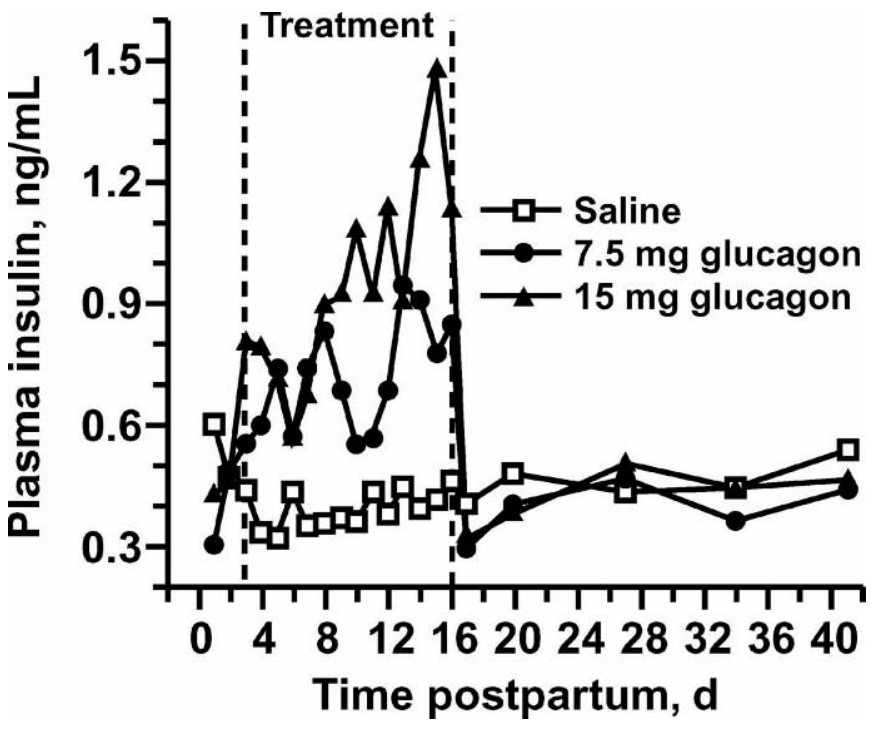

Figure 4. Plasma insulin concentration of cows treated with saline, $7.5 \mathrm{mg}$, and $15 \mathrm{mg}$ of glucagon per day. Glucagon effects during the treatment period differed for 7.5- and 15-mg doses $(P<0.05$ and $P<0.01$, respectively). During the posttreatment period, effects were not significant for 7.5- and 15-mg doses. Time effects during treatment and posttreatment periods were not significant. Treatment $\times$ time interaction was not detected during the treatment and posttreatment periods $(\mathrm{SEM}=0.05$ to 0.08 )

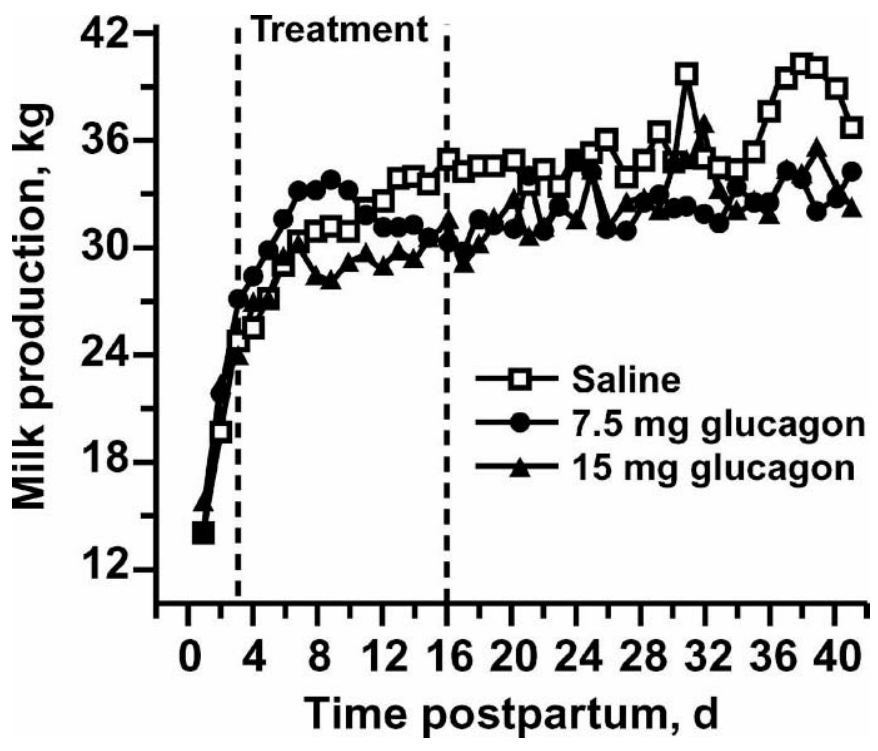

Figure 5. Milk production of cows treated with saline, $7.5 \mathrm{mg}$, and $15 \mathrm{mg}$ of glucagon per day. Glucagon effects during the treatment period were not significant for 7.5- and $15-\mathrm{mg}$ doses. During the posttreatment period, effects were not significant for 7.5- and 15-mg doses. Time effects during treatment and posttreatment periods were detected $(P<0.001$ and $P<0.05$, respectively). A treatment $\times$ time interaction was not detected during treatment and posttreatment periods $(\mathrm{SEM}=1.32$ to 2.79$)$. glycogen synthesis, as was shown in rodent in vitro studies (Jiang and Zhang, 2003), because liver glycogen concentrations were greater in glucagon-treated groups throughout the study. After glucagon administration was terminated, liver glycogen concentrations increased, peaking at d 20 to 27 postpartum, which was similar to changes in liver glycogen concentrations after termination of glucagon administration reported earlier (Hippen et al., 1999). The huge increase in liver glycogen concentrations and no differences in plasma glucose concentrations between glucagon and control groups after the cessation of glucagon administration suggest that greater rates of gluconeogenesis occurred in liver tissues of cows treated with glucagon. Evidently, rate-limiting enzymes of gluconeogenesis were up-regulated in liver tissues of cows treated with glucagon after the end of glucagon administration, which caused the extra glucose production and glycogen synthesis.

Plasma glucose concentrations increased during glucagon administration, which agrees with earlier results (De Boer et al., 1986; Hippen et al., 1999; Bobe et al., 2003b). The increase in plasma glucose concentrations probably resulted from activation of gluconeogenesis through phosphoenolpyruvate carboxykinase and propionyl-CoA carboxylase, rate-limiting gluconeogenic enzymes (Velez and Donkin, 2005), or repartitioning of glucose from use in glycolysis in peripheral tissues (Connolly et al., 2000).

Plasma NEFA concentrations declined substantially during glucagon administration (Figure 3B), which agrees with earlier studies (Hippen et al., 1999; Bobe et al., 2003b). Monitoring plasma NEFA in dairy herds is a valuable tool for identifying late-gestating cows that are in negative energy balance (Oetzel, 2004). Because elevated prepartum plasma NEFA concentrations are associated with more metabolic disorders after parturition, a NEFA threshold of $500 \mu M$ was defined, suggesting that the cows exceeding this threshold would have greater likelihood for developing postpartum disorders (Oetzel, 2004; LeBlanc et al., 2005). No defined threshold for plasma NEFA, however, exists for postpartum cows. On the basis of data in Figures $1 \mathrm{~A}$ and 3B, we propose that, when postpartum cows have plasma NEFA concentrations not exceeding $400 \mu M$, the likelihood of developing fatty liver by those cows will be minimal.

Our results agree with recent findings in human subcutaneous adipose tissue in vivo (Jensen et al., 1991; Bertin et al., 2001) suggesting that glucagon has no direct effect on rates of lipolysis. Some earlier studies, however, indicated in vivo and in vitro lipolytic effects of glucagon (Carlson et al., 1993; Perea et al., 1995). Most likely, an increase in plasma insulin concentra- 

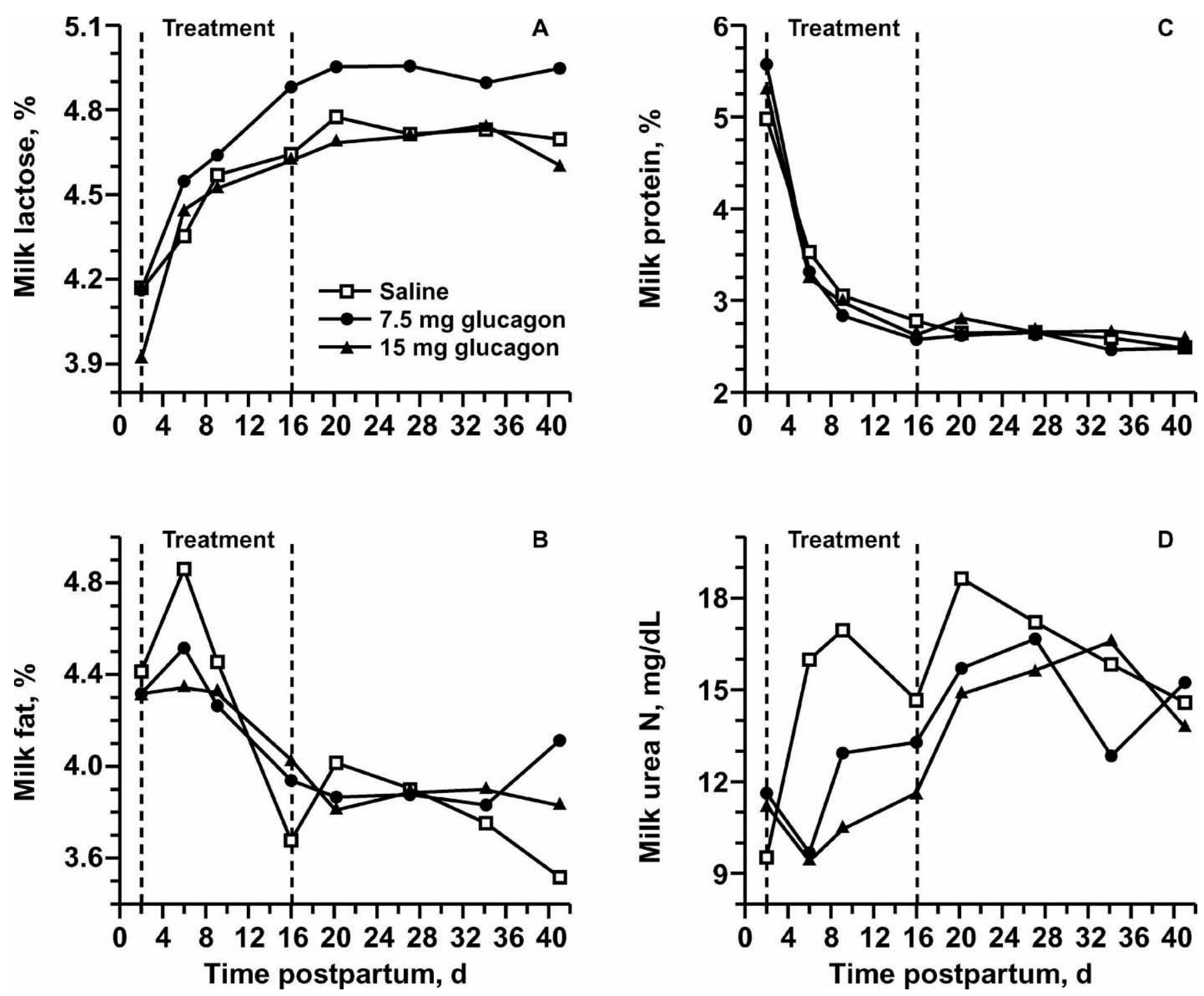

Figure 6. Milk composition of cows treated with saline, $7.5 \mathrm{mg}$, and $15 \mathrm{mg}$ of glucagon per day. A) Milk lactose. Glucagon effects during the treatment period were not significant. During the posttreatment period, effects were not significant for 7.5- and 15-mg doses. Time effects during the treatment period were detected $(P<0.001)$. Time effects during the posttreatment period were not significant. Treatment $\times$ time interactions for the treatment and posttreatment periods were not detected (SEM $=0.078$ to 0.083 ). B) Milk fat. Glucagon effects during the treatment period were not significant for 7.5- and 15-mg doses. During the posttreatment period, effects were not significant for 7.5- and 15-mg doses. Time effects during the treatment period were detected $(P<0.01)$. Time effects during the posttreatment period were not significant. Treatment $\times$ time interactions for the treatment and posttreatment periods were not significant $(\mathrm{SEM}=0.11$ to 0.22$)$. C) Milk protein. Glucagon effects during treatment were not significant for 7.5- and 15-mg doses. During the posttreatment period, effects were not significant for 7.5- and 15-mg doses. Time effects for the treatment and posttreatment periods were detected $(P<0.001$ and $P<$ 0.05 , respectively). Treatment $\times$ time interactions for the treatment and posttreatment periods were not detected (SEM $=0.052$ to 0.098 ). D) Milk urea N. Glucagon effects during treatment were detected for 7.5 - and 15-mg doses $(P<0.05$ and $P<0.01$, respectively). During the posttreatment period, effects were not significant for 7.5- and 15-mg doses. Time effects for the treatment and posttreatment periods were not significant. Treatment $\times$ time interactions for the treatment and posttreatment periods were not detected $(\mathrm{SEM}=0.55$ to 1.34$)$.

tions after glucagon administration suppresses lipolysis (Elks and Manganiello, 1985) or enhances reesterification of NEFA into TAG in adipose tissue (Campbell et al., 1992). Elevated blood glucose concentrations (Figure 3A) may enhance the antilipolytic action of insulin (Arner et al., 1983).
Plasma BHBA concentrations (Figure 3C) were mostly below $14.6 \mathrm{mg} / \mathrm{dL}(1,400 \mu M)$, which is the threshold for the development of subclinical ketosis (Oetzel, 2004; LeBlanc et al., 2005). Similar concentrations were observed (Bobe et al., 2003b), but diet supplementation with 1,3-butanediol caused a dramatic in- 


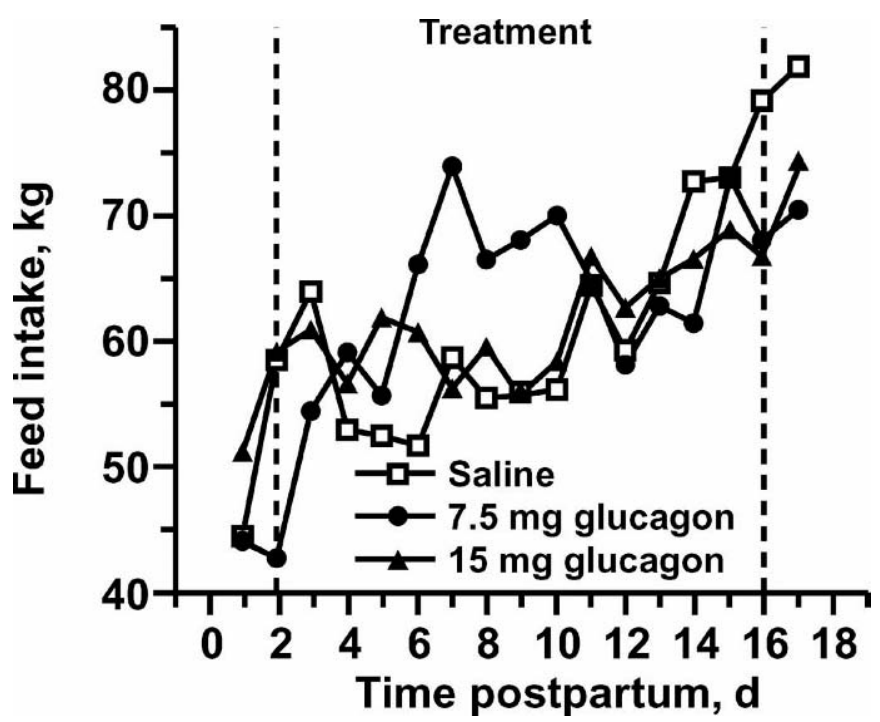

Figure 7. Feed intake of cows treated with saline, $7.5 \mathrm{mg}$, and $15 \mathrm{mg}$ of glucagon per day. Glucagon effects during the treatment period were not significant for $7.5-$ and $15-\mathrm{mg}$ doses. Time effects during the treatment period were not significant. A treatment $\times$ time interaction during the treatment period was not detected $(\mathrm{SEM}=$ 4.28 to 6.12 ).

crease in plasma BHBA concentrations of up to $30 \mathrm{mg} /$ dL (Hippen et al., 1999). It seems that plasma BHBA concentrations observed in the present study and in another study (Bobe et al., 2003b) are similar to those occurring in cows with mild fatty liver during the transi-

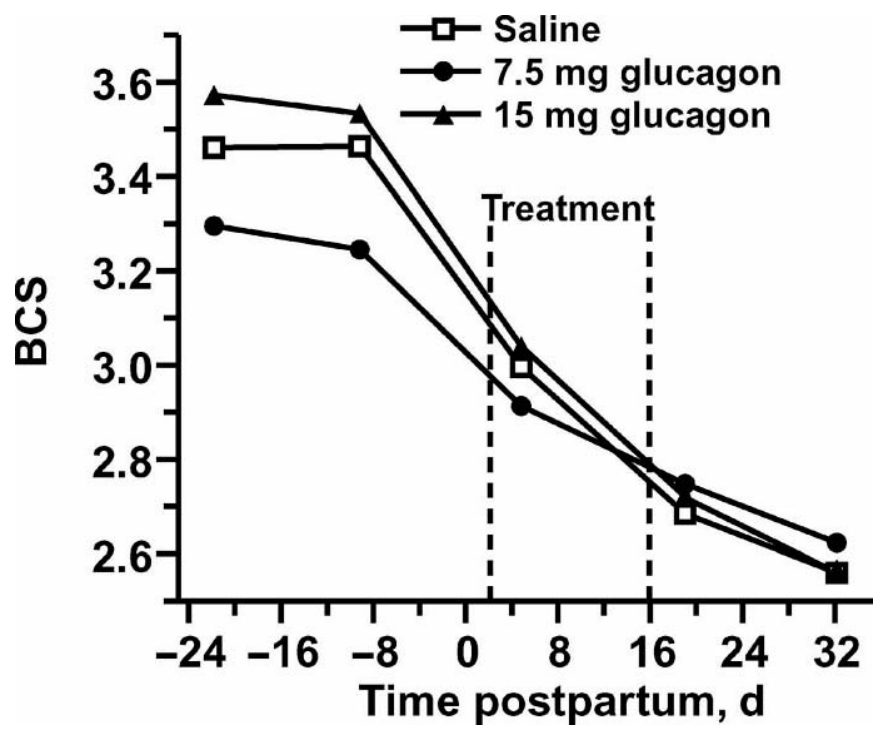

Figure 8. Body condition scores of cows treated with saline, 7.5 $\mathrm{mg}$, and $15 \mathrm{mg}$ of glucagon per day. Differences in BCS between saline and the 7.5-mg dose of glucagon, saline and 15-mg dose, and 7.5- and 15-mg dose of glucagon throughout the study did not differ $(\mathrm{SEM}=0.12$ to 0.23 ). tion period. Our results support the statement that cows developing mild fatty liver during the first $3 \mathrm{wk}$ of lactation do not necessarily develop ketosis (Holtenius and Holtenius, 1996). When cows reach the peak of lactation, however, they may be more likely to develop fatty liver and ketosis.

Plasma BHBA concentrations in the control (Figure 3C) were elevated around d 9 postpartum probably because of elevated liver TAG (Figure 1B) and reduced concentrations of liver glycogen (Figure 2) in those cows around that time (Drackley et al., 1992). Cows given glucagon at the 15-mg dose also had elevated plasma BHBA concentrations, which might be explained by glucagon-activated liver carnitine palmitoyltransferase 1 (Louet et al., 2002). Cows receiving the 7.5-mg dose of glucagon did not have elevated plasma ketone-body concentrations, probably because glucagon dosage was not large enough to stimulate ketogenesis. Plasma BHBA concentrations were elevated above $14.6 \mathrm{mg} / \mathrm{dL}$ $(1,400 \mu M)$ threshold (Oetzel, 2004) at least once during the treatment period in 4,2 , and 2 cows in the control, 7.5 , and $15 \mathrm{mg}$ doses of glucagon, respectively. Urinary acetoacetate concentrations were elevated above the 40 $\mathrm{mg} / \mathrm{dL}$ threshold (Carrier et al., 2004) at least once during the treatment period in 4, 3, and 3 cows from saline, 7.5-, and 15-mg doses of glucagon, respectively. These results show again that glucagon-treated cows in our study failed to develop even subclinical ketosis and did not have different concentrations of ketone bodies compared with those of the control. Moreover, plasma BHBA and urinary acetoacetate concentrations changed during the treatment period in a similar way, suggesting that both tests might be used interchangeably for detecting cows with subclinical and clinical ketosis.

Plasma urea $\mathrm{N}$ concentrations (Figure 3D) were not affected by glucagon administration, which agrees with earlier studies (Hippen et al., 1999; Bobe et al., 2003b). Our results provide indirect evidence that glucagon does not increase use of amino acids as gluconeogenic precursors.

Injections of glucagon caused a large increase in concentrations of plasma insulin, which was sustained until the treatment period ended (Figure 4A). The data agree with our earlier report (She et al., 1999b). A steep rise in plasma insulin concentrations greater than 0.9 $\mathrm{ng} / \mathrm{mL}$ occurred after $\mathrm{d} 8$ postpartum in cows given 15 $\mathrm{mg}$ of glucagon, which led to a substantial decrease in plasma NEFA. Based on the results in Figures $3 \mathrm{~B}$ and $4 \mathrm{~A}$, the decrease in plasma NEFA concentrations below the $400 \mu M$ threshold, which is necessary for prevention of liver TAG accumulation, can be achieved if plasma insulin concentrations are greater than $0.9 \mathrm{ng} / \mathrm{mL}$. In- 
hibitory effects of insulin on lipolysis were shown previously (Elks and Manganiello, 1985).

Milk production (Figure 5) was unaffected by glucagon and did not differ between either of the glucagontreated groups and the control throughout the study, which agrees with earlier results (Bobe et al., 2003b). In addition, lactose concentrations in milk (Figure 4A) did not differ among groups throughout the study, as observed earlier (Bobe et al., 2003b). However, lactose concentrations in milk in cows given $7.5 \mathrm{mg}$ of glucagon were slightly greater than those in milk in the other 2 groups. Aside from variability among cows, it is difficult to explain the cause of increased lactose concentrations in cows given $7.5 \mathrm{mg}$ of glucagon, but our results indicate no direct relationship between blood glucose concentrations and lactose biosynthesis.

Milk fat concentrations (Figure 6B) were not changed by glucagon as observed earlier (Bobe et al., 2003b). Concentrations, however, were slightly greater in the control around d 6 postpartum, when those cows also exhibited greater plasma NEFA concentrations. In general, for cows having the same milk production, milk fat concentrations seemed to be correlated positively with plasma NEFA concentrations. Milk protein concentrations (Figure 6C) were not altered by glucagon, which agrees with an earlier study (Bobe et al., 2003b). Our results indicate that glucagon did not facilitate use of amino acids as gluconeogenic precursors during the periparturient period. With the exception of alanine, contributions of amino acids to glucose biosynthesis usually are not changed significantly in transition dairy cows (Reynolds et al., 2003). Milk urea N concentrations (Figure 6D) were decreased by glucagon, as reported earlier (Bobe et al., 2003b). This observation indicates that glucagon did not increase protein use for glucose biosynthesis during the periparturient period, which agrees with observations for untreated cows during the same period (Reynolds et al., 2003).

Feed intake (Figure 7) was unaffected by glucagon, which agrees with an earlier study (Bobe et al., 2003b). Cows given $7.5 \mathrm{mg}$ of glucagon tended to have slightly greater feed intake around d 9 postpartum, which can be explained by lower ketone body concentrations in blood and urine (Goff and Horst, 1997). Subcutaneous injections of glucagon did not decrease feed intake as observed during intravenous administration of glucagon (Hippen et al., 1999; She et al., 1999a). Surprisingly, increases in plasma glucose stimulated by glucagon were not accompanied by increases in feed intake, suggesting that cows do not depend entirely on extra gluconeogenic precursors to support increased blood glucose and insulin concentrations as suggested by Gerloff (2000). It also suggests that the early postpartum suppression of gluconeogenesis mostly is responsible for the limitation of using glucose precursors available in feed (Rukkwamsuk et al., 1999).

Based on our results, we propose that prevention of fatty liver in transition dairy cows by glucagon may occur by the following mechanism. Exogenous glucagon increases blood glucose concentrations by up-regulating hepatic gluconeogenesis and repartitioning glucose from being used in glycolysis in peripheral tissues. Glucagon also stimulates the release of pancreatic insulin by acting directly on the pancreas and indirectly by increased blood glucose concentrations. Elevated concentrations of blood glucose and insulin then inhibit lipolysis in adipose tissue and stimulate blood NEFA reuptake and reesterification into adipose tissue, leading to a decrease in blood NEFA concentrations. Reduced concentrations of blood NEFA then prevent excessive accumulation of hepatic TAG and thus development of fatty liver.

There have been attempts to increase glucose and insulin concentrations in blood by using dietary manipulations such as drenching with propylene glycol (Pickett et al., 2003) or adding a gluconeogenic precursor (i.e., glycerol) to diets (DeFrain et al., 2004), but those manipulations did not lead to a substantial increase in blood glucose concentrations and did not change blood insulin concentrations. In addition, slow-release insulin was tested in healthy Holstein cows to determine its effect on liver TAG, blood NEFA, and glucose concentrations (Hayirli et al., 2002). Although administration of slow-release insulin moderately decreased liver TAG and blood NEFA concentrations, treatment with insulin did not increase or even sustain blood glucose concentrations. Consequently, glucagon administration is the only treatment known to increase blood glucose and insulin concentrations, and at the same time, decrease blood NEFA and liver TAG concentrations in transition dairy cows.

The results of our study can be applied to general dairy herd populations even though our cows developed only mild fatty livers with TAG concentrations not exceeding $10 \%$. According to Jorritsma et al. (2000a), the majority of cows in commercial dairy herds develop mild fatty livers. Cows developing fatty liver before calving because of increased prepartum plasma NEFA concentrations (Oetzel, 2004; LeBlanc et al., 2005) can be treated postpartum with glucagon to decrease the extent of fatty liver ontogeny. Glucagon treatment also can be given to dairy cows with fatty liver to speed up the recovery process. Glucagon administration, however, has not yet been approved by federal agencies for use by dairy producers.

Further studies should include monitoring of prepartum plasma NEFA concentrations as a tool for selecting cows susceptible to postpartum development of fatty 
liver. Glucagon administration to prevent fatty liver may be more effective when initiated at calving because of the ability of glucagon to cause an earlier decrease in plasma NEFA concentrations below the $400 \mu M$ threshold. As a result, less plasma NEFA will be able to enter the liver, be esterified, and stored as TAG. Effectiveness of glucagon injections might be improved by supplementing diets with different gluconeogenic precursors such as glycerol. Glucagon administration during 2 wk before parturition, if approved, may be another management approach to reduce plasma NEFA concentrations in cows susceptible to fatty liver development.

\section{CONCLUSIONS}

Our results show that subcutaneous injections of the 15 -mg dose of glucagon for $14 \mathrm{~d}$ beginning on $\mathrm{d} 2$ postpartum prevented development of fatty liver in transition dairy cows. Subcutaneous injections of glucagon increased plasma glucose and insulin concentrations, decreased rates of lipolysis from adipose tissue, and possibly increased rates of blood NEFA reesterification to form TAG in adipose tissue, causing a decrease in plasma NEFA concentrations. As a result, accumulation of liver TAG was prevented in the group receiving the 15-mg daily dose of glucagon. Administering glucagon at the 7.5-mg dose was less effective. The increase in plasma glucose concentrations in response to glucagon injections was probably caused by activation of gluconeogenesis and possibly an increase in glucose repartitioning from use as an energy source. Glucagon did not deplete liver glycogen. No negative effects of glucagon administration were detected on feed intake, or milk production and its composition. Glucagon injections decreased milk urea $\mathrm{N}$ concentrations and tended to decrease plasma urea $\mathrm{N}$ concentrations, suggesting a role for glucagon in improvement of dietary and body protein use. No significant effects of glucagon were detected on rates of ketogenesis. Considered as a composite, these changes indicate that glucagon might be a useful tool to control fatty liver disease in transition dairy cows.

\section{ACKNOWLEDGMENTS}

The authors thank Swiss Valley Farms (Davenport, IA) for analysis of milk samples, and Eli Lilly (Indianapolis, IN) for providing the glucagon. This research was partly supported by grant number 99-35005-8576 from the U.S. Department of Agriculture and was part of the regional research project NC-1009. Appreciation is also extended to the management and staff of the Iowa State University Dairy Farm for providing cows and facilities, and to many undergraduate and veterinary medical students who assisted with collection and analysis of liver and blood samples.

\section{REFERENCES}

Allain, C. C., L. S. Poon, C. S. Chan, W. Richmond, and P. C. Fu. 1974. Enzymatic determination of total serum cholesterol. Clin. Chem. 20:470-475.

Arner, P., J. Bolinder, and J. Ostman. 1983. Glucose stimulation of the antilipolytic effect of insulin in humans. Science 220:1057-1059.

Bertin, E., P. Arner, J. Bolinder, and E. Hagstrom-Toft. 2001. Action of glucagon and glucagon-like peptide-1-(7-36) amide on lipolysis in human subcutaneous adipose tissue and skeletal muscle in vivo. J. Clin. Endocrinol. Metab. 86:1229-1234.

Bobe, G., B. N. Ametaj, J. W. Young, and D. C. Beitz. 2003a. Effects of exogenous glucagon on lipids in lipoproteins and liver of lactating dairy cows. J. Dairy Sci. 86:2895-2903.

Bobe, G., B. N. Ametaj, J. W. Young, and D. C. Beitz. 2003b. Potential treatment of fatty liver with 14-day subcutaneous injections of glucagon. J. Dairy Sci. 86:3138-3147.

Bobe, G., J. W. Young, and D. C. Beitz. 2004. Invited review: Pathology, etiology, prevention, and treatment of fatty liver in dairy cows. J. Dairy Sci. 87:3105-3124.

Campbell, P. J., M. G. Carlson, J. O. Hill, and N. Nurjhan. 1992. Regulation of free fatty acid metabolism by insulin in humans: Role of lipolysis and reesterification. Am. J. Physiol. 263:E1063-E1069.

Carlson, M. G., W. L. Snead, and P. J. Campbell. 1993. Regulation of free fatty acid metabolism by glucagon. J. Clin. Endocrinol. Metab. 77:11-15.

Carrier, J., S. Stewart, S. Godden, J. Fetrow, and P. Rapnicki. 2004. Evaluation and use of three cowside tests for detection of subclinical ketosis in early postpartum cows. J. Dairy Sci. 87:3725-3735.

Connolly, C. C., L. C. Holste, L. N. Aglione, D. W. Neal, D. B. Lacy, M. S. Smith, M. P. Diamond, A. D. Cherrington, and J. L. Chiasson. 2000. Alterations in basal glucose metabolism during late pregnancy in the conscious dog. Am. J. Physiol. Endocrinol. Metab. 279:E1166-E1177.

DeBoer, G., A. Trenkle, and J. W. Young. 1986. Secretion and clearance rates of glucagon in dairy cows. J. Dairy Sci. 69:721-733.

DeFrain, J. M., A. R. Hippen, K. F. Kalscheur, and P. W. Jardon. 2004. Feeding glycerol to transition dairy cows: Effects on blood metabolites and lactation performance. J. Dairy Sci. 87:41954206

Drackley, J. K., M. J. Richard, D. C. Beitz, and J. W. Young. 1992. Metabolic changes in dairy cows with ketonemia in response to feed restriction and dietary 1,3-butanediol. J. Dairy Sci. 75:1622-1634.

Drackley, J. K. 1999. ADSA Foundation Scholar Award: Biology of dairy cows during the transition period: The final frontier. J. Dairy Sci. 82:2259-2273.

Elks, M. L., and V. C. Manganiello. 1985. Antilipolytic action of insulin: Role of cAMP phosphodiesterase activation. Endocrinology 116:2119-2121.

Folch, J., M. Lees, and G. H. Sloane Stanley. 1957. A simple method for the isolation and purification of total lipids from animal tissues. J. Biol. Chem. 226:497-509.

Fossati, P., and L. Prencipe. 1982. Serum triglycerides determined colorimetrically with an enzyme that produces hydrogen peroxide. Clin. Chem. 28:2077-2080.

Fourichon, C., H. Seegers, N. Bareille, and F. Beaudeau. 1999. Effects of disease on milk production in the dairy cow: A review. Prev. Vet. Med. 41:1-35.

Gerloff, B. J. 2000. Dry cow management for the prevention of ketosis and fatty liver in dairy cows. Vet. Clin. North Am. Food Anim. Pract. 16:283-292.

Goff, J. P., and R. L. Horst. 1997. Physiological changes at parturition and their relationship to metabolic disorders. J. Dairy Sci. 80:1260-1268. 
Greenfield, R. B., M. J. Cecava, T. R. Johnson, and S. S. Donkin. 2000. Impact of dietary protein amount and rumen undegradability on intake, peripartum liver triglyceride, plasma metabolites, and milk production in transition dairy cattle. J. Dairy Sci. 83:703710.

Grummer, R. R. 1993. Etiology of lipid-related metabolic disorders in periparturient dairy cows. J. Dairy Sci. 76:3882-3896.

Hansen, J. L., and E. F. Freier. 1978. Direct assays of lactate, pyruvate, beta-hydroxybutyrate, and acetoacetate with a centrifugal analyzer. Clin. Chem. 24:475-479.

Hayirli, A., S. J. Bertics, and R. R. Grummer. 2002. Effects of slowrelease insulin on production, liver triglyceride, and metabolic profiles of Holsteins in early lactation. J. Dairy Sci. 85:2180-2191.

Herdt, T. H. 2000. Ruminant adaptation to negative energy balance. Influences on the etiology of ketosis and fatty liver. Vet. Clin. North Am. Food Anim. Pract. 16:215-230.

Hippen, A. R., P. She, J. W. Young, D. C. Beitz, G. L. Lindberg, L. F. Richardson, and R. W. Tucker. 1999. Alleviation of fatty liver in dairy cows with 14-day intravenous infusions of glucagon. J. Dairy Sci. 82:1139-1152.

Holtenius, P., and K. Holtenius. 1996. New aspects of ketone bodies in energy metabolism of dairy cows: A review. Zentralbl. Veterinarmed. A 43:579-587.

Jenkins, K. J., and J. K. Kramer. 1990. Effects of dietary corn oil and fish oil concentrate on lipid composition of calf tissues. J. Dairy Sci. 73:2940-2951.

Jensen, M. D., V. J. Heiling, and J. M. Miles. 1991. Effects of glucagon on free fatty acid metabolism in humans. J. Clin. Endocrinol. Metab. 72:308-315.

Jiang, G., and B. B. Zhang. 2003. Glucagon and regulation of glucose metabolism. Am. J. Physiol. Endocrinol. Metab. 284:E671-E678.

Jorritsma, R., H. Jorritsma, Y. H. Schukken, P. C. Bartlett, T. Wensing, and G. H. Wentink. 2000a. Prevalence and indicators of post partum fatty infiltration of the liver in nine commercial dairy herds in The Netherlands. Livest. Prod. Sci. 68:53-60.

Jorritsma, R., H. Jorritsma, Y. H. Schukken, and G. H. Wentink. 2000b. Relationships between fatty liver and fertility and some periparturient diseases in commercial Dutch dairy herds. Theriogenology 54:1065-1074.

Jorritsma, R., T. Wensing, T. A. Kruip, P. L. Vos, and J. P. Noordhuizen. 2003. Metabolic changes in early lactation and impaired reproductive performance in dairy cows. Vet. Res. 34:11-26.

Katoh, N. 2002. Relevance of apolipoproteins in the development of fatty liver and fatty liver-related peripartum diseases in dairy cows. J. Vet. Med. Sci. 64:293-307.

LeBlanc, S. J., K. E. Leslie, and T. F. Duffield. 2005. Metabolic predictors of displaced abomasum in dairy cattle. J. Dairy Sci. 88:159-170.

Louet, J. F., G. Hayhurst, F. J. Gonzalez, J. Girard, and J. F. Decaux. 2002. The coactivator PGC-1 is involved in the regulation of the liver carnitine palmitoyltransferase I gene expression by cAMP in combination with HNF-4 alpha and cAMP-response elementbinding protein (CREB). J. Biol. Chem. 277:37991-38000.

Mills, S. E., D. C. Beitz, and J. W. Young. 1986a. Characterization of metabolic changes during a protocol for inducing lactation ketosis in dairy cows. J. Dairy Sci. 69:352-361.

Mills, S. E., D. C. Beitz, and J. W. Young. 1986b. Evidence for impaired metabolism in liver during induced lactation ketosis of dairy cows. J. Dairy Sci. 69:362-370.
Oetzel, G. R. 2004. Monitoring and testing dairy herds for metabolic disease. Vet. Clin. North Am. Food Anim. Pract. 20:651-674.

Perea, A., F. Clemente, J. Martinell, M. L. Villanueva-Penacarrillo, and I. Valverde. 1995. Physiological effect of glucagon in human isolated adipocytes. Horm. Metab. Res. 27:372-375.

Pickett, M. M., M. S. Piepenbrink, and T. R. Overton. 2003. Effects of propylene glycol or fat drench on plasma metabolites, liver composition, and production of dairy cows during the periparturient period. J. Dairy Sci. 86:2113-2121.

Reynolds, C. K., P. C. Aikman, B. Lupoli, D. J. Humphries, and D. E. Beever. 2003. Splanchnic metabolism of dairy cows during the transition from late gestation through early lactation. J. Dairy Sci. 86:1201-1217.

Rukkwamsuk, T., T. Wensing, and M. J. Geelen. 1999. Effect of fatty liver on hepatic gluconeogenesis in periparturient dairy cows. J. Dairy Sci. 82:500-505.

She, P., A. R. Hippen, J. W. Young, G. L. Lindberg, D. C. Beitz, L. F. Richardson, and R. W. Tucker. 1999a. Metabolic responses of lactating dairy cows to 14-day intravenous infusions of glucagon. J. Dairy Sci. 82:1118-1127.

She, P., G. L. Lindberg, A. R. Hippen, D. C. Beitz, and J. W. Young. 1999b. Regulation of messenger ribonucleic acid expression for gluconeogenic enzymes during glucagon infusions into lactating cows. J. Dairy Sci. 82:1153-1163.

Takayama, M., S. Itoh, T. Nagasaki, and I. Tanimizu. 1977. A new enzymatic method for determination of serum choline-containing phospholipids. Clin. Chim. Acta 79:93-98.

Talke, H., and G. E. Schubert. 1965. Enzymatic urea determination in the blood and serum in the Warburg optical test. Klin. Wochenschr. 43:174-175.

Trinder, P. 1969. Determination of blood glucose using an oxidaseperoxidase system with a non-carcinogenic chromogen. J. Clin. Pathol. 22:158-161.

Van Den Top, A. M., M. J. Geelen, T. Wensing, G. H. Wentink, A. T. Van'T Klooster, and A. C. Beynen. 1996. Higher postpartum hepatic triacylglycerol concentrations in dairy cows with free rather than restricted access to feed during the dry period are associated with lower activities of hepatic glycerolphosphate acyltransferase. J. Nutr. 126:76-85

Van Den Top, A. M., T. Wensing, M. J. Geelen, G. H. Wentink, A. T. Van'T Klooster, and A. C. Beynen. 1995. Time trends of plasma lipids and enzymes synthesizing hepatic triacylglycerol during postpartum development of fatty liver in dairy cows. J. Dairy Sci. 78:2208-2220.

Van Winden, S. C., R. Jorritsma, K. E. Muller, and J. P. Noordhuizen. 2003. Feed intake, milk yield, and metabolic parameters prior to left displaced abomasum in dairy cows. J. Dairy Sci. 86:14651471.

Velez, J. C., and S. S. Donkin. 2005. Feed restriction induces pyruvate carboxylase but not phosphoenolpyruvate carboxykinase in dairy cows. J. Dairy Sci. 88:2938-2948.

Wentink, G. H., T. S. van den Ingh, V. P. Rutten, K. E. Muller, and T. Wensing. 1999. Reduced lymphoid response to skin allotransplants in cows with hepatic lipidosis. Vet. Q. 21:68-69.

Zerbe, H., N. Schneider, W. Leibold, T. Wensing, T. A. Kruip, and H. J. Schuberth. 2000. Altered functional and immunophenotypical properties of neutrophilic granulocytes in postpartum cows associated with fatty liver. Theriogenology 54:771-786. 